\title{
EMPLOYEE SATISFACTION WITH THE PHYSICAL WORK ENVIRONMENT: THE IMPORTANCE OF A NEED BASED APPROACH
}

\author{
Bart BUDIE ${ }^{1}$, Rianne APPEL-MEULENBROEK ${ }^{1, *}$, \\ Astrid KEMPERMAN ${ }^{1}$, Minou WEIJS-PERREE ${ }^{1}$ \\ ${ }^{1}$ Department of the Built Environment, Eindhoven University of Technology, P.O. Box 513, VRT 8.B14, \\ 5600 MB Eindhoven, The Netherlands
}

Received 14 April 2017; accepted 15 January 2018

\begin{abstract}
Employee satisfaction is pivotal for companies as it enhances perceived productivity and organizational performance. Office concepts and their workspaces can affect employee satisfaction. However, these effects are still ambiguous, particularly regarding the activity-based concept. Therefore, in this study employee satisfaction with the work environment is investigated from a holistic approach. The effects of both personal characteristics and workspaces used by the employee on work environment satisfaction are described and measured, including mediating effects of the perceived importance of employee needs. Data was collected using an online questionnaire among 327 employees of 13 knowledge-based organizations. Path analysis was used to determine the direct and indirect effects of personal variables, environmental variables and perceived importance of needs on satisfaction. It demonstrated that both personal and environmental variables affect satisfaction, and that a considerable number of these effects are indirect through the perceived importance of needs. In particular, the effects of used workspaces were extensive.
\end{abstract}

Keywords: employee needs, work environment satisfaction, activity-based office concept, workplace use, workplace management.

\section{Introduction}

In contemporary knowledge-based economies, it is pivotal for companies to foster employee satisfaction. Various authors claimed that employee satisfaction can enhance productivity and organizational performance (e.g., De Been \& Beijer, 2014; Lee \& Brand, 2005; Veitch, Charles, Farley, \& Newsham, 2007). Raising satisfaction with the physical work environment has therefore also become a major corporate real estate strategy in practice (Jensen, 2011). For work environment satisfaction, Van der Voordt (2004) coined a useful definition, namely the extent to which the physical work environment meets the employee needs. This definition is also adopted in this study.

Many studies have been conducted on the effects of the work environment on satisfaction with it, often focusing on differences between various office concepts or workspaces (e.g., Bodin-Danielsson \& Bodin, 2008; De Been \& Beijer, 2014; Van der Voordt, Brunia, \& AppelMeulenbroek, 2017). In particular, the comparison between cell offices and open-plan offices is prevailing in literature (e.g., Kim \& de Dear, 2013). Cell offices are generally found to be satisfactory, while open-plan offices often demonstrate inferior results (e.g., Bodin-Danielsson \& Bodin, 2008; Kim \& de Dear, 2013). Although open office environments are assumed to be beneficial for communication, they are consistently associated with several drawbacks, such as distraction, lack of privacy, insufficient storage space, and a poor indoor climate (e.g., Brennan, Chugh, \& Kline, 2002; Kamarulzaman, Saleh, Hashim, Hashim, \& Abdul-Ghani, 2011; Kim \& de Dear, 2013; Sanoff, 1985). These effects differ between small open plan offices (also known as team offices) and larger open plan offices (Bodin-Danielsson \& Bodin, 2008).

In the 1990s, a renewing office concept arose, namely the activity-based office concept (Appel-Meulenbroek, Groenen, \& Janssen, 2011). The rapid IT developments enabled employees to work time and place independently. In activity-based offices (ABOs), the workspaces are therefore generally not assigned to individual employees. Instead, they should be used based on the conducted activity (Becker, 1999). Thus, ABOs can best be described as non-

*Corresponding author. E-mail: h.a.j.a.appel@tue.nl 
territorial offices, with a variety of workspaces - both open and enclosed - to support the various activities conducted by the employees (Brunia, De Been, \& Van der Voordt, 2016; Khamkanya \& Sloan, 2009). Both the use of these offices and the physical appearance of the workspaces differ from conventional offices.

ABOs are often implemented for the assumed benefits for work environment satisfaction and employee productivity, as well as cost reduction (Van der Voordt, 2004). However, ABOs also comprise many open workspaces, which might demonstrate the same drawbacks as conventional open-plan offices. For example, Gorgievski, Van der Voordt, Van Herpen, and Van Akkeren (2010) conducted a post occupancy evaluation in an activity-based work environment and found similar drawbacks, such as the lack of privacy and concentration. Moreover, Van der Voordt and Van Meel (2002) argued that desk-sharing leads to additional drawbacks, namely the violation of psychological needs such as personalization. Also, the inadequate use of these offices might negatively affect work environment satisfaction (e.g., Hoendervanger, Le Noble, Mobach, \& Van Yperen, 2015). On the other hand, there are also several benefits associated with the $\mathrm{ABO}$ concept. Gorgievski et al. (2010) found that employees valued the increased opportunities for communication, and indicated that additional enclosed workspaces might reduce the drawbacks. The increased autonomy is also an important advantage (Ekstrand, Damman, Hansen, \& Hatling, 2015; Vos \& Van der Voordt, 2002). Additionally, the superior aesthetics (e.g., Van der Voordt, 2004) and ergonomics (e.g., Vos \& Van der Voordt, 2002) might compensate drawbacks. Nevertheless, hard evidence is still scarce, and research shows inconsistent results (Van der Voordt, 2004; Brunia et al., 2016).

As mentioned above, satisfaction with the physical work environment can best be described as the extent to which the physical work environment meets the employee needs (Van der Voordt, 2004). It is thus expected that the drawbacks and benefits of $\mathrm{ABO}$ are related to how important employees consider certain needs, such as the need for privacy or the need for personalization, and hence affect work environment satisfaction. Although numerous studies focus on the effects of office concept or workspaces on work environment satisfaction, employee needs (or their importance) are not always included as explanatory variables in such studies. Employee needs are generally only described (e.g., Hills \& Levy, 2014), ranked (e.g., Fleming, 2005) or used as independent variable (e.g., Rothe, Lindholm, Hyvönen, \& Nenonen, 2011). Also, the use of the workplace and time spent on certain activities are not always included. Therefore, in this study a holistic, need-based approach was adopted to study satisfaction with the physical work environment. The main aim was to integrate the many bivariate relationships tested in prior studies into one model to test which relationships remain significant in this overall model. The following research question is answered in this study: To what extent do differences in personal characteristics, activity patterns and used workspaces affect employee satisfaction with the physical work environment in different office concepts? And which of these effects are mediated by the perceived importance of specific employee needs?

In the next section, the existing research on these relationships and the relevant needs are presented and developed into a conceptual model. Then, the methodology is described to test the proposed model, followed by the results. This paper ends with a discussion and conclusions.

\section{Theoretical framework}

\subsection{Direct effects on satisfaction}

Existing research often focused on the direct effects of the work environment on employee satisfaction with it (e.g., Bodin-Danielsson \& Bodin, 2008; De Been \& Beijer, 2014). Recently, the differences between the ABO concept and conventional offices also gained momentum in research (e.g., Appel-Meulenbroek, Kemperman, Van Susante, \& Hoendervanger, 2015b; Van der Voordt, 2004). Moreover, the specific workspace used within these office concepts and its direct effect on work environment satisfaction is explored. For example, Kim and de Dear (2013) examined differences in satisfaction between employees with different workspaces in conventional offices, while Hoendervanger et al. (2015) focused on the effects of workspace use on work environment satisfaction in ABOs. These studies show that the work environment in general, different office concepts, and the specific workspace use significantly affect satisfaction. Therefore, the first main variable in our study is the used workspace(s).

In addition to effects of the workspace, work environment satisfaction research generally also includes the direct effects of personal characteristics such as age and gender, which have been shown to be significant (e.g., Bodin-Danielsson \& Bodin, 2008; De Been \& Beijer, 2014). Hartog, Weijs-Perrée, and Appel-Meulenbroek (2018) also found that personality affects satisfaction with the work environment in multi-tenant offices. Also, as $\mathrm{ABO}$ s have different types of workspaces for different activities, it can be assumed that an employee's activities could influence work environment satisfaction (De Been \& Beijer, 2014). For employees that mainly conduct work that requires concentration, it is likely that a noisy open workspace might be less satisfactory compared to employees whose main activity involves non-concentrated work. So, it can be concluded that other important variables assumed to influence work environment satisfaction are personal characteristics and activity patterns.

To further clarify the complex relationship between the offered work environment and work environment satisfaction, the field of environmental psychology provides useful insights (Oseland, 2009; Vischer, 2008). Stallworth and Kleiner (1996) advocated that the Person-Environment fit theory is specifically useful in this context. There has to be a fit between the work environment and the needs of the employee in order to foster 
satisfaction. Needs are thus also a variable in this study with a direct relationship with work environment satisfaction. Vischer (2008) provided a useful categorization of needs, including the need for physical comfort, functional comfort, and psychological comfort. Physical comfort concerns needs that are important in generally all buildings, which largely concerns the physiological needs for environmental comfort. Functional comfort refers to the work-related needs, while psychological comfort encompasses psychological needs (Vischer, 2008). These three categories are adopted in this study, thus relevant needs were inventoried from the existing literature for all three categories (see Figure 1).

As mentioned, physical comfort needs relate to the ambient factors, such as temperature and air quality. Dissatisfaction with climate comfort can also negatively affect productivity (Haynes, 2008; Roelofsen, 2002). Fleming (2005) assessed the importance of a large number of aspects, and found that particularly aspects that relate to visual comfort (lighting) score high on importance, but temperature was also among the most important aspects. Furthermore, personal control over the indoor climate is an important need (e.g., Batenburg \& Van der Voordt, 2008a, 2008b). Although Vischer (2008) designated control as a psychological need, it is placed in the physical comfort need category due to its strong connection to the indoor climate. To conclude, it is assumed that physical comfort needs encompass climate comfort, visual comfort, and control over climate comfort.

Functional comfort concerns the extent to which the work environment supports the conducted tasks and thus the performance of the employees (Vischer, 2008). It is therefore necessary to understand the nature of these tasks. According to Heerwagen, Kampschroer, Powell, and
Loftness (2004), both communicative tasks and individual, concentrated tasks are essential for knowledge work. Both concentration and communication are consistently found to be among the most important needs (e.g., Batenburg \& Van der Voordt, 2008b; Maarleveld, Volker, \& Van der Voordt, 2009). Related to communication, Fleming (2005) and Appel-Meulenbroek et al. (2011) found that the proximity and accessibility of coworkers is important. Furthermore, the functionality of the workspace and furniture should sufficiently support work activities. That is, the dimensions of the furniture should be sufficient, because employees need space to conduct their work adequately (Hills \& Levy, 2014). Additionally, Ding (2008) found that storage space was perceived as important. Lastly, the comfort of the furniture - thus ergonomics - is of high importance (e.g., Appel-Meulenbroek et al., 2011). Thus, functional needs encompass concentration, communication, proximity of coworkers, space, storage space, and ergonomics (as shown in Figure 1).

Last, employees also have psychological needs. Even though these needs are not work-related, they can still affect satisfaction with the office environment (Vischer, 2008). Van der Voordt and Van Meel (2002) explored the relevant psychological needs, and distinguished the needs for social interaction, privacy, territoriality, personalization, status expression and aesthetics. Additionally, the need for autonomy (e.g., Ekstrand et al., 2015) and relaxation (e.g., Jahncke, Hygge, Halin, Green, \& Dimberg, 2011) are important to consider in the work environment. In particular, privacy receives much attention in research, and can be regarded as control over social interaction (Haans, Kaiser, \& De Kort, 2007). Related to privacy, employees want to have their own territory, as a means to assert this control (Van der Voordt \& Van Meel, 2002).

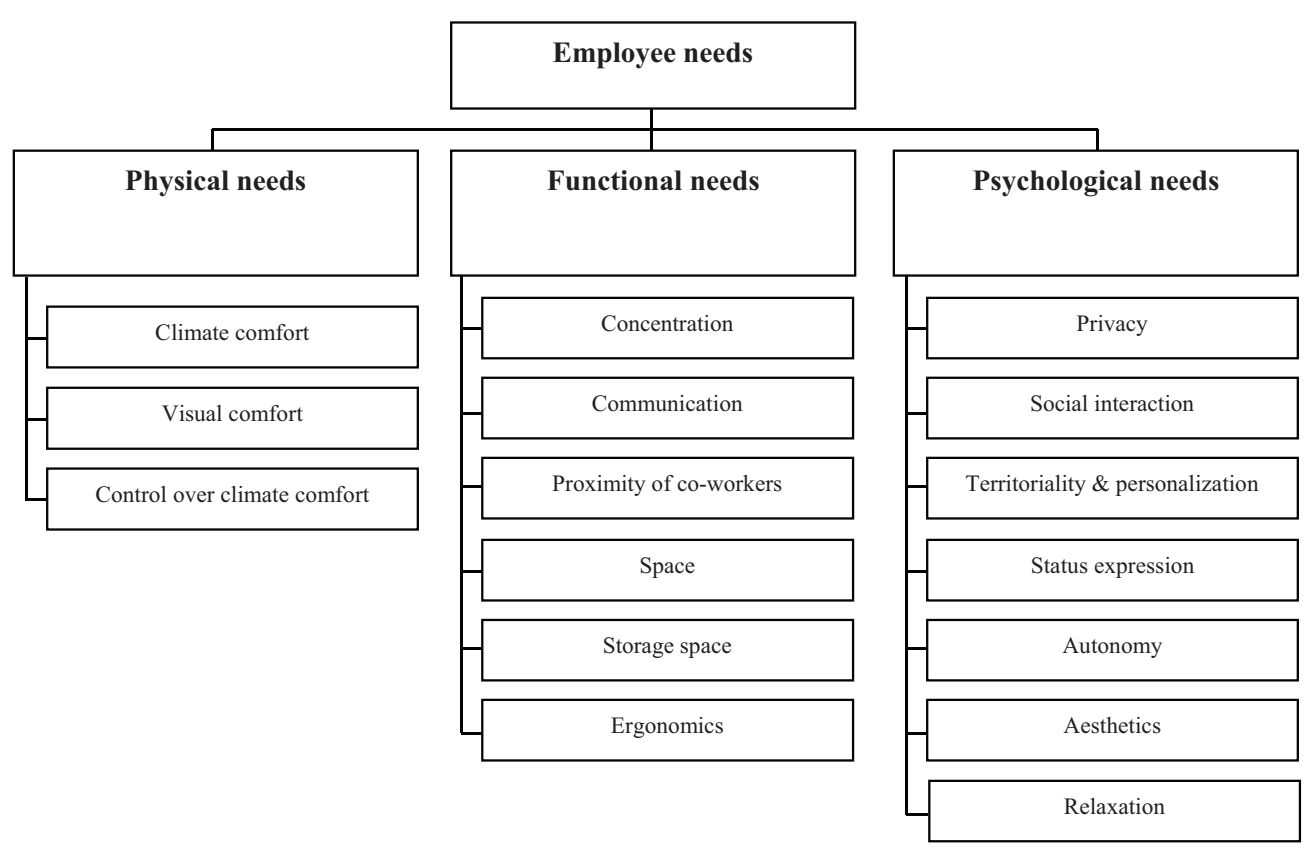

Figure 1. Overview of relevant employee needs, derived from the literature study 
Therefore, this need might lead to personalization of the workspace (Brown, 2009). Brunia and Hartjes-Gosselink (2009) found that this need is even expressed in non-territorial offices, where personalization is actually discouraged. Thus, the psychological needs are privacy, social interaction, territoriality, status expression, autonomy, aesthetics, and relaxation.

\subsection{Indirect effects through employee needs}

The perceived importance of specific needs might further clarify the effects of the workspace, personal characteristics and activities on their work environment satisfaction. For example, Rothe et al. (2011) found significant effects of several personal characteristics on their preferences for the work environment. It is therefore assumed that the effects of personal characteristics on work environment satisfaction are at least partly mediated by the importance of employee needs.

For example, previous studies consistently showed that gender is relevant for the need for climate comfort, with female employees being generally more dissatisfied with the indoor climate (e.g., Choi, Aziz, \& Loftness, 2010; Karjalainen, 2012). Dinç (2009) also found that female employees tend to attach more importance to personalization, while status expression is perceived as more important by male employees. Moreover, age and generational differences have received attention in the literature. For example, Joy and Haynes (2011) focused on choice behavior and found that the oldest generation of employees uses enclosed workspaces more frequently, both for individual work and for formal communication. These findings might indicate that privacy is more important for older employees. On the other hand, the youngest generation of employees (Generation Y) is generally described as team players, and finds communication more important. The importance of status expression might also differ between generations, because the oldest generation values hierarchy, while younger generations refute this (Earle, 2003).

Additionally, Oseland (2009) claims that personality affects needs, and argues that extraversion might determine how important communication and privacy are. However, personality is more complex, and four additional person- ality traits are generally distinguished to complete the 'Big Five': agreeableness, conscientiousness, emotional stability, and openness to experience (e.g., Bozionelos, 2004; Gosling, Rentfrow, \& Swann, 2003). Little research has been conducted on the effects of these personality traits on work environment needs. Nevertheless, Bakker, Van der Voordt, Vink, De Boon, and Bazley (2015), for example, found that personality could affect color preferences, which might be relevant regarding interior design.

The importance of specific functional needs might particularly be determined by activity patterns. For example, Venezia and Allee (2007) argue that the social role of the work environment is particularly important for mobile employees. Also, various studies include task complexity to assess privacy needs (e.g., Maher \& Von Hippel, 2005).

The characteristics of the current work environment (i.e., office concept and workspace use) might also influence needs, although little empirical evidence of this relationship is found in the literature. Nevertheless, the awareness and importance of a need might increase when it is unmet in the current work environment. On the other hand, it is also assumable that employees learn to cope with the unmet need and adapt to this situation. For example, Van der Voordt (2004) indicated that employees in $\mathrm{ABOs}$ eventually learn to cope with the loss of the possibility to personalize. Therefore, it is also assumed that the perceived importance of needs might partly mediate some effects between the current workspace and work environment satisfaction.

\subsection{Conceptual model}

To conclude, the importance employees attach to certain needs plays an essential role in satisfaction research. As discussed in this section, this importance might mediate the effects of both the used workspace(s) and personal characteristics and activity patterns, in addition to the direct effects of these variables on satisfaction with the physical work environment. Figure 2 shows the conceptual model that summarizes these effects, and visualizes the holistic approach adopted in this study. Whereas prior studies mainly focused on the separate bivariate relationships included in this model, this study aims to test all these relationships simultaneously.

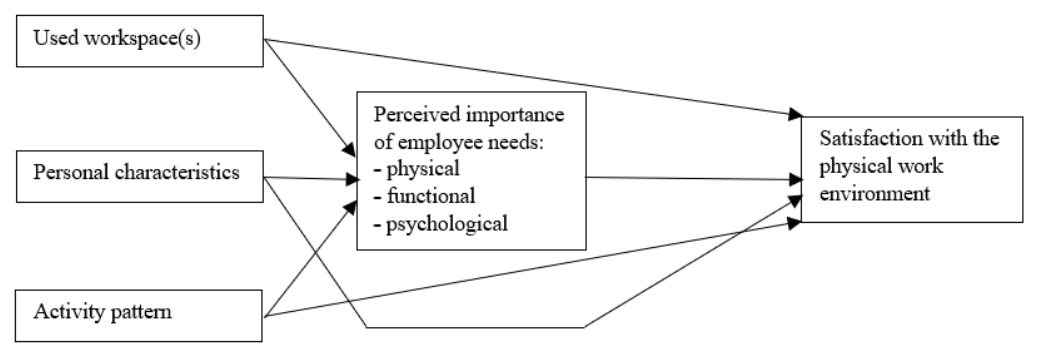

Figure 2. Conceptual model 


\section{Methodology}

To test the conceptual model that describes the various factors, environmental satisfaction data was needed. To collect these data, an online questionnaire was developed. For this questionnaire, the different concepts of the conceptual model were operationalized into measurable variables.

\subsection{Questionnaire}

In the online survey questions to measure all the concepts of the proposed model are included.

Workspace - The workspace of the individual employee included the office concept (ABO or designated seating) and capacity. Cell offices may have a capacity of up to three employees (Bodin-Danielsson \& Bodin, 2008; De Been \& Beijer, 2014). For the open plan areas in the conventional offices, a distinction can be made between small open plans, also known as team offices (four to nine employees), and larger open plans (ten or more employees) (e.g., Bodin-Danielsson \& Bodin, 2008; Duffy, 1997). For $\mathrm{ABOs}$, this distinction is less applicable, because the actual number of employees present may vary widely from the capacity. Furthermore, as the name suggests, the team office should accommodate members of the same team (Duffy, 1997), which is unlikely in non-territorial work environments. But $\mathrm{ABOs}$ do also have concentration cells besides open and cellular workspaces and employees are likely to use more than one workspace. Thus, for each of these workspaces, the respondents were asked whether they use it or not. As a result, six dummy variables are created, namely: 'cell office in conventional office', 'team office in conventional office, 'open-plan office in conventional office', 'open space in ABO', 'cell office in ABO', and 'concentration cell in ABO'. Thus, these variables encompass the used workspace, as well as the office concept (conventional or $\mathrm{ABO}$ ).

Activity patterns - Activity pattern was operationalized using the following activities: 'individual concentration work', 'individual non-concentrated work', 'formal faceto-face communication', 'informal face-to-face communication', and 'phone calls'. The respondents were asked to distribute their working hours (on average in one week) over these activities. Based on the distribution, the relative time spent on each activity was determined.

Personality - For personality, the personality traits of the Big Five were measured using the TIPI (Gosling et al., 2003). This measure includes two items per personality trait (one positive and one reversed), measured on a seven point scale. This measure is concise, but has proven to be sufficiently reliable (Gosling et al., 2003).

External mobility, gender, age - Besides activity patterns, Rothe et al. (2011) used three main characteristics to explore differences in preferences, namely external mobility (number of hours outside the office) and the personal characteristics age and gender. External mobility was operationalized as the time spent away from the office during working hours. Thus, both the total working hours and the hours spent at the office are asked. For age, the year of birth is asked, and gender is asked directly.

Perceived importance of employee needs - For the assessment of need importance, the aspects presented in Figure 1 were used: concentration, privacy, communication, proximity of coworkers, space, storage space, climate comfort, lighting (visual comfort), control over climate comfort, personalization, status expression, aesthetics, relaxation, and autonomy and freedom in choice. The importance employees attach to each of these needs is asked, using a five-point Likert scale (ranging from 'not important at all' to 'very important').

Work environment satisfaction - In this study, satisfaction with the physical work environment is seen as the extent to which the work environment meets (or satisfies) the employee needs. The employees were asked to state their satisfaction with the same aspects distinguished for the need importance assessment, also on a five-point Likert scale (ranging from 'very dissatisfied' to 'very satisfied').

\subsection{Data collection and sample}

Thirteen knowledge-based organizations, located in the Netherlands, participated in this study, and distributed the online questionnaire among their employees. The organizations vary from housing associations and municipalities to consultancy firms, so both the non-profit and the profit sector are represented (see Table 1). The selection of these organizations was largely based on a snowball sample, meaning that the selection method is

Table 1. Characteristics of the included organizations

\begin{tabular}{|l|l|c|c|}
\hline \multicolumn{1}{|c|}{ Type of organization } & Office concept & Sample & Response \\
\hline Higher education & Conventional & 43 & 13 \\
\hline Building installations & Conventional & 96 & 14 \\
\hline Housing association A & Activity-based & 30 & 11 \\
\hline Housing association B & Activity-based & 100 & 35 \\
\hline Housing association C & Conventional & 252 & 92 \\
\hline Consultancy (real estate) A & Activity-based & 9 & 3 \\
\hline Consultancy (real estate) B & Activity-based & 10 & 5 \\
\hline Consultancy (real estate) C & Activity-based & 13 & 9 \\
\hline Consultancy (real estate) D & Conventional & 7 & 6 \\
\hline Construction/Consultancy & Activity-based & 136 & 43 \\
\hline Municipality A & Conventional & 96 & 28 \\
\hline Municipality B, building 1 & Conventional & $100^{*}$ & 7 \\
\hline Municipality B, building 2 & Activity-based & & 9 \\
\hline Life sciences & Activity-based & 120 & 50 \\
\hline Unknown & & & 2 \\
\hline
\end{tabular}

Note: ${ }^{*}$ - Due to random distribution of the questionnaire within the organization, it is not known how the employees of the sample are distributed over the two buildings. 
not random. This method negatively affects the generalizability, but was useful to acquire sufficient respondents in both conventional offices and $\mathrm{ABO}$. The response rate was $32.3 \%$, with 327 of the 1014 contacted employees returning the questionnaire. Of these 327 cases, 322 were useful for the analyses.

Table 2 summarizes the sample characteristics. The dispersion of gender and the average age are quite similar to the samples in the studies of De Been and Beijer (2014) and Batenburg and Van der Voordt (2008b). Concerning activity patterns, individual work represents almost half of the work hours, which is again similar to previous studies (e.g., Vos \& Van der Voordt, 2002). This is beneficial for the generalizability of our study. There are 164 respondents in ABOs. Of these employees, 150 use open spaces, 47 use cell offices and 66 use concentration cells. Thus, almost all employees in $\mathrm{ABO}$ use open spaces, and most of these employees also use cell offices and/or concentration cells. The 158 employees in conventional offices generally use only one specific workspace, because these are assigned, but some employees do use more than one workspace.

Table 2. Sample characteristics

\begin{tabular}{|l|c|c|}
\hline \multicolumn{1}{|c|}{$\mathrm{N}=322$} & $\begin{array}{c}\text { Average / } \\
\text { count }\end{array}$ & $\begin{array}{c}\text { Standard } \\
\text { deviation }\end{array}$ \\
\hline Gender & & \\
Male & $195(60.6 \%)$ & \\
Female & $127(39.4 \%)$ & \\
\hline Age & 44.3 & 11 \\
\hline External mobility & $19.4 \%$ & 22.1 \\
\hline Activities & & \\
Individual concentration work & $43.7 \%$ & 21.9 \\
Individual non-concentrated work & $16.5 \%$ & 14.2 \\
Formal communication & $20.5 \%$ & 16.6 \\
Informal communication & $6.0 \%$ & 5.9 \\
Phone calls & $10.0 \%$ & 12.2 \\
Other & $3.3 \%$ & 7.0 \\
\hline Activity-based office & $164(50.9 \%)$ & \\
Use of open space & 150 & \\
Use of cell office & 47 & \\
Use of concentration cell & 66 & \\
\hline Conventional office & $158(49.1 \%)$ & \\
Use of cell office & 97 & \\
Use of team office & 52 & \\
Use of open space & 24 & \\
\hline
\end{tabular}

\subsection{Procedure}

In order to test the proposed conceptual model with the assumed direct and indirect relationships, path analysis was required. Path analysis is a variant on structural equation modelling, though only using observed variables (Jöreskog \& Sörbom, 2008). This method assesses multiple effects simultaneously. Not only the effects of independent variables on dependent variables are estimated, but also the relationships between independent and mediating variables and between mediating and dependent variables
(Jöreskog \& Sörbom, 2008). Therefore, path analysis is a suitable method to test the indirect relationships through importance of needs in the conceptual model, while simultaneously assessing the direct effects of the independent variables on work environment satisfaction. For conducting the path analysis, the software package LISREL is used. However, the number of variables and consequently the number of possible relationships is quite extensive in this study. In order to reduce the number of variables in the path analysis, the mediating variables - the importance scores - and the dependent variables - the satisfaction scores - were reduced using principal component analysis (PCA). For both analyses, Varimax rotation was used, and the number of new components was based on the eigenvalue criterion, meaning that the eigenvalue of the components should be higher than 1. Furthermore, bivariate analyses - Chi square tests, t-tests, and Pearson correlations - were conducted beforehand, to exclude the insignificant relationships from the path model.

\section{Findings}

First, to reduce the number of variables to be included in the path model, five distinct need components were derived from the PCA on the importance scores (see Table 3):

- Comfort (indoor climate, control over indoor climate, lighting, ergonomics, space).

- Territoriality (space, storage space, personalization, status expression).

- Pleasantness (autonomy, aesthetics, relaxation).

- Communication (communication, proximity of coworkers).

- Privacy (privacy, concentration).

The explained variance of these five components is $60.5 \%$. Moreover, to test the internal consistency of the set of items for each factor Cronbach's alpha scores ( $>2$ variables) and the inter-items correlation coefficient (2 variables) were calculated and included in Tables 3 and 4. They show acceptable results (meaning $>0.6$ for the Cronbach's alpha and in between 0.2 and 0.5 for the inter items correlation). These five components show some analogy with the three categories in section 1 . Territoriality and pleasantness cover psychological needs, privacy and communication largely concern functional needs, and comfort encompasses the physical needs and some functional needs.

Secondly, the work environment satisfaction scores were reduced using the same procedure, shown in Table 4, also leading to five components:

- Regulation of interaction (communication, proximity of coworkers, concentration, privacy).

- Indoor climate (indoor climate, control over indoor climate, lighting).

- Pleasantness (autonomy, relaxation, aesthetics, ergonomics).

- Influence (personalization, status expression, storage space, autonomy).

- Functionality (space, storage space, ergonomics). 
Table 3. Principal components analysis of need scores

\begin{tabular}{|c|c|c|c|c|c|}
\hline \multirow[b]{2}{*}{ Variables: Importance of: } & \multicolumn{5}{|c|}{ Components } \\
\hline & 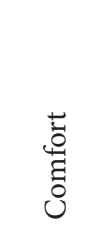 & 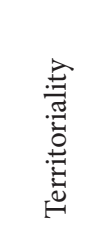 & 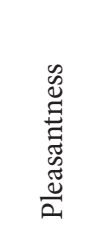 & 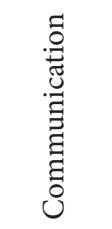 & 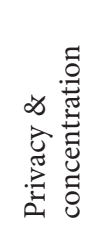 \\
\hline climate comfort & 0.841 & 0.042 & 0.108 & -0.023 & 0.090 \\
\hline control over climate & 0.689 & 0.229 & 0.044 & -0.080 & 0.126 \\
\hline ergonomics & 0.677 & 0.186 & 0.048 & 0.159 & -0.071 \\
\hline lighting & 0.673 & -0.053 & 0.188 & -0.064 & 0.275 \\
\hline space & 0.489 & 0.541 & 0.102 & 0.118 & -0.107 \\
\hline storage space & 0.279 & 0.768 & -0.026 & 0.064 & -0.012 \\
\hline personalization & 0.030 & 0.700 & 0.202 & -0.059 & 0.316 \\
\hline status expression & 0.017 & 0.686 & 0.285 & -0.101 & 0.081 \\
\hline autonomy and freedom in choice & 0.190 & -0.048 & 0.760 & 0.020 & -0.030 \\
\hline relaxation & 0.049 & 0.195 & 0.715 & 0.085 & 0.052 \\
\hline aesthetics & 0.076 & 0.301 & 0.672 & 0.094 & 0.063 \\
\hline proximity of coworkers & 0.016 & 0.045 & 0.070 & 0.813 & -0.173 \\
\hline communication & -0.016 & -0.092 & 0.118 & 0.730 & 0.292 \\
\hline privacy & 0.045 & 0.118 & 0.115 & -0.092 & 0.770 \\
\hline concentration & 0.285 & 0.089 & -0.111 & 0.270 & 0.602 \\
\hline Eigenvalue & 3.775 & 1.609 & 1.425 & 1.155 & 1.104 \\
\hline$\%$ of explained variance & $25.17 \%$ & $10.73 \%$ & $9.50 \%$ & $7.70 \%$ & $7.36 \%$ \\
\hline Cronbach's alpha/Inter items correlation & 0.757 & 0.709 & 0.638 & 0.312 & 0.209 \\
\hline
\end{tabular}

Table 4. Principal components analysis of satisfaction scores

\begin{tabular}{|c|c|c|c|c|c|}
\hline \multirow[b]{2}{*}{ Variables: satisfaction with } & \multicolumn{5}{|c|}{ Components } \\
\hline & 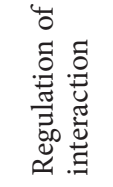 & 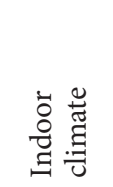 & 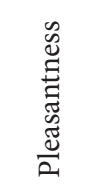 & $\begin{array}{l}\stackrel{\mathscr{\Xi}}{\Xi} \\
\stackrel{\Xi}{\Xi}\end{array}$ & 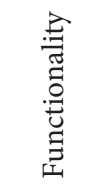 \\
\hline concentration & 0.834 & 0.063 & 0.129 & 0.106 & 0.031 \\
\hline privacy & 0.793 & 0.179 & 0.075 & 0.247 & 0.028 \\
\hline communication & 0.775 & 0.087 & 0.153 & 0.078 & 0.102 \\
\hline proximity of coworkers & 0.467 & 0.046 & 0.224 & 0.064 & 0.266 \\
\hline climate comfort & 0.045 & 0.902 & 0.129 & 0.075 & 0.070 \\
\hline control over climate & 0.052 & 0.892 & 0.086 & 0.209 & -0.035 \\
\hline lighting & 0.305 & 0.547 & 0.100 & 0.019 & 0.161 \\
\hline relaxation & 0.205 & 0.023 & 0.715 & 0.359 & 0.030 \\
\hline aesthetics & 0.068 & 0.282 & 0.662 & 0.046 & 0.078 \\
\hline ergonomics & 0.199 & 0.039 & 0.651 & -0.204 & 0.429 \\
\hline autonomy and freedom in choice & 0.317 & 0.067 & 0.608 & 0.425 & -0.026 \\
\hline status expression & 0.093 & 0.129 & 0.308 & 0.798 & 0.037 \\
\hline personalization & 0.251 & 0.149 & 0.004 & 0.790 & 0.111 \\
\hline storage space & 0.117 & 0.128 & -0.127 & 0.414 & 0.741 \\
\hline space & 0.122 & 0.053 & 0.306 & -0.068 & 0.819 \\
\hline Eigenvalue & 4.733 & 1.666 & 1.417 & 1.237 & 1.113 \\
\hline$\%$ of explained variance & $31.55 \%$ & $11.11 \%$ & $9.45 \%$ & $8.25 \%$ & $7.42 \%$ \\
\hline Cronbach's alpha & 0.771 & 0.763 & 0.721 & 0.681 & 0.617 \\
\hline
\end{tabular}


The explained variance of these five components is $67.8 \%$. It is interesting to see that the importance components differ from the satisfaction components. This difference might be explained by the notion that the importance is related more to the employee, while work environment satisfaction is inevitably related to the work environment that is used at that time (Rothe et al., 2011). For example, privacy and communication are distinct needs, but regarding work environment satisfaction, they are related, because both aspects are affected by the number of interactions in the work environment.

\subsection{Path model estimation}

The newly created components for importance and satisfaction scores were used as mediating and dependent variables respectively in the model. The personal characteristics, including activities and personality, and workspace variables were used as independent variables.

Bivariate analyses were conducted beforehand, in order to assess which relationships were significant and should be included in the path model. Relationships that were not significant at the 0.05 level in the bivariate analyses are excluded from the path model. Furthermore, relationships that did not remain significant at the 0.05 level in the path model are removed stepwise. The variables 'openness to experience, 'time spent on individual concentration work', 'time spent on formal communication', 'time spent on informal communication' and 'use of cell office in $\mathrm{ABO}$ ' had no significant effects in the path model and are therefore excluded.

Figure 3 shows the estimated final path model. The goodness-of-fit of the model was assessed using several parameters, as shown in Table 5. The RMSEA of the estimated model is 0.012 . This value should be lower than 0.05 to show a good fit of the model (Golob, 2001), so the model is sufficiently adequate. Moreover, the ratio between the Chi square and the degrees of freedom should be less than 2 (Golob, 2001). For this model, the value is 1.08 , which is good. The CFI (0.99), GFI (0.96) and AGFI (0.92) are all higher than 0.9 , thus also indicating a good fit. Thus, based on these measures, it can be concluded that the estimated path model has a good fit.

As can be seen in Figure 3, the path model encompasses both direct and indirect effects (running through

Table 5. Goodness-of-fit measures of the estimated path model

\begin{tabular}{|l|c|}
\hline Degrees of freedom & 158 \\
\hline Minimum fit function Chi-square & 170.81 \\
\hline Chi-square/degrees of freedom & 1.08 \\
\hline RMSEA & 0.012 \\
\hline Model AIC & 449.25 \\
\hline Saturated AIC & 600.00 \\
\hline GFI & 0.96 \\
\hline AGFI & 0.92 \\
\hline CFI & 0.99 \\
\hline
\end{tabular}

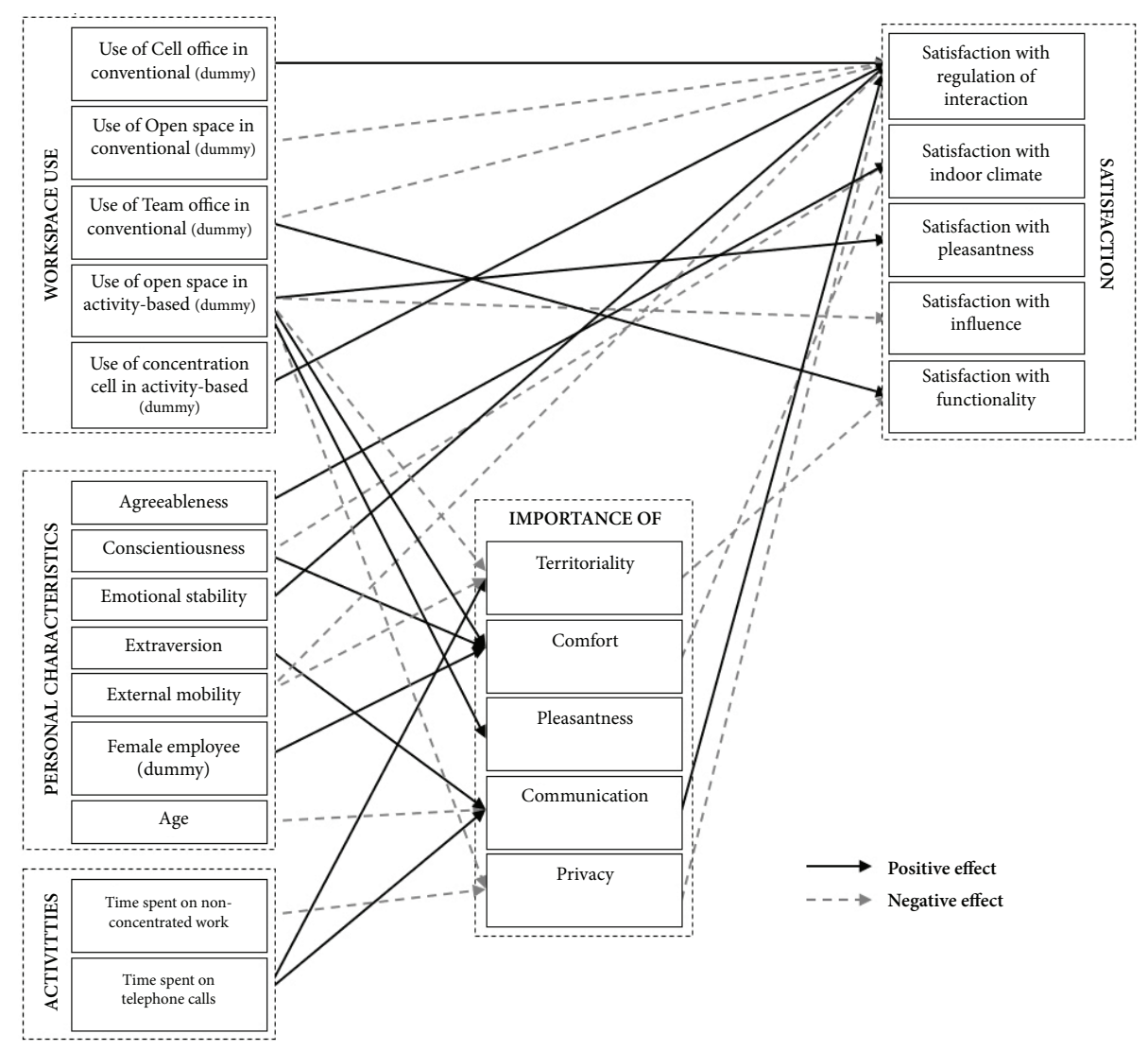

Figure 3. Final path model 
perceived importance of the employees' needs). The indirect effects are from both the workspace variables and the personal variables. These effects are discussed subsequently.

\subsection{Effects of independent variables on perceived importance of needs}

Table 6 shows the standardized effects of the various independent variables on the perceived importance of needs. The path analysis confirmed that there might be a relationship between the use of the work environment and needs. The use of open spaces in ABOs is positively related to the importance of comfort $(\beta=0.17 ; t=3.18)$. On the other hand, the use of open spaces in ABOs is negatively associated with the importance of privacy $(\beta=-0.17 ; t=$ $-3.01)$ and territoriality $(\beta=-0.18 ; t=3.29)$. Last, pleasantness was more important for those using open spaces in $\mathrm{ABOs}(\beta=0.13$; $t=2.33)$.

Furthermore, several personal characteristics significantly affected the perceived importance of certain needs. The importance of communication was negatively associated with age ( $\beta=-0.29 ; t=-5.44)$ and positively associated with the personality trait extraversion $(\beta=0.15$; $t=2.82)$. The importance of comfort was higher for females $(\beta=0.14 ; t=2.53)$. Additionally, the personality trait conscientiousness positively affected the importance of comfort ( $\beta=0.25 ; t=4.69)$. External mobility negatively affected the importance of territoriality $(\beta=-0.21$; $t=-3.70)$. It is indeed likely that employees who spend less time at the office attach lower importance to having their own territory. Regarding the activities, the time spent on non-concentrated work is negatively associated with the importance of privacy $(\beta=-0.16 ; t=-2.96)$. Furthermore, the time spent on phone calls is positively related to the importance of communication $(\beta=0.12 ; t=2.32)$ and territoriality $(\beta=0.17 ; t=2.93)$. Surprisingly, the time spent on concentration work and communication did not significantly relate to perceived importance nor to satisfaction in this study.

\subsection{Effects on work environment satisfaction}

The work environment satisfaction scores were affected by the importance scores and the independent variables, as can be seen in Table 7. Thus, the path analysis confirmed that there are direct relationships between the perceived importance of needs and their satisfaction with certain aspects of the work environment. Most of these relationships were negative. As can be seen in Table 7, a higher importance of comfort is negatively associated with satisfaction with the indoor climate $(\beta=-0.15 ; t=-2.54)$, and a higher importance of territoriality is negatively associated with satisfaction with functionality $(\beta=-0.31 ; t=$ $-5.65)$. The latter effect is likely, because functionality also covered space in this study (see Table 4). Furthermore, a higher importance of privacy is negatively associated with satisfaction with the regulation of interaction $(\beta=-0.16$; $t=-3.03$ ). On the other hand, a higher importance of communication is positively associated with the satisfaction with this aspect $(\beta=0.13 ; t=-2.48)$. This might imply that the offices in this sample are generally beneficial for communication.

The work environment variables affected the work environment satisfaction scores considerably, confirming previous bivariate studies. In conventional offices, satisfaction with the regulation of interaction was higher in cell offices ( $\beta=0.30 ; t=-5.03)$, and lower in team offices $(\beta=$ $-0.13 ; t=-2.34)$ and open spaces $(\beta=-0.15 ; t=-2.82)$. Furthermore, satisfaction with the functionality was high-

Table 6. Direct effects on needs (standardized)

\begin{tabular}{|c|c|c|c|c|c|c|c|c|c|c|}
\hline \multirow[b]{2}{*}{ Effects of independent variables } & \multicolumn{2}{|c|}{$\begin{array}{l}\text { Importance of } \\
\text { comfort }\end{array}$} & \multicolumn{2}{|c|}{$\begin{array}{l}\text { Importance of } \\
\text { territoriality }\end{array}$} & \multicolumn{2}{|c|}{$\begin{array}{l}\text { Importance of } \\
\text { pleasantness }\end{array}$} & \multicolumn{2}{|c|}{$\begin{array}{l}\text { Importance of } \\
\text { communication }\end{array}$} & \multicolumn{2}{|c|}{$\begin{array}{l}\text { Importance of } \\
\text { privacy }\end{array}$} \\
\hline & $\beta$ & $t$ & $\beta$ & $t$ & $\beta$ & $t$ & $\beta$ & $t$ & $\beta$ & $t$ \\
\hline \multicolumn{11}{|l|}{ Use of cell office, conventional } \\
\hline \multicolumn{11}{|l|}{ Use of open space, conventional } \\
\hline \multicolumn{11}{|l|}{ Use of team office, conventional } \\
\hline Use of open space, activity-based & 0.17 & 3.18 & -0.18 & -3.29 & 0.13 & 2.33 & & & -0.17 & -3.01 \\
\hline \multicolumn{11}{|l|}{ Use of concentr. cell, activity-based } \\
\hline Age & & & & & & & -0.29 & -5.44 & & \\
\hline Female employee (dummy) & 0.14 & 2.53 & & & & & & & & \\
\hline Extraversion & & & & & & & 0.15 & 2.82 & & \\
\hline \multicolumn{11}{|l|}{ Agreeableness } \\
\hline Conscientiousness & 0.25 & 4.69 & & & & & & & & \\
\hline \multicolumn{11}{|l|}{ Emotional stability } \\
\hline External mobility & & & -0.21 & -3.70 & & & & & & \\
\hline Time on non-concentrated work & & & & & & & & & -0.16 & -2.96 \\
\hline Time on phone calls & & & 0.17 & 2.93 & & & 0.12 & 2.32 & & \\
\hline
\end{tabular}


Table 7. Direct effects on satisfaction (standardized)*

\begin{tabular}{|c|c|c|c|c|c|c|c|c|c|c|}
\hline \multirow[b]{2}{*}{ Effects of needs } & \multicolumn{2}{|c|}{$\begin{array}{l}\text { Satisfaction with } \\
\text { regulation of } \\
\text { interaction }\end{array}$} & \multicolumn{2}{|c|}{$\begin{array}{l}\text { Satisfaction with } \\
\text { indoor climate }\end{array}$} & \multicolumn{2}{|c|}{$\begin{array}{c}\text { Satisfaction with } \\
\text { pleasantness }\end{array}$} & \multicolumn{2}{|c|}{$\begin{array}{l}\text { Satisfaction with } \\
\text { influence }\end{array}$} & \multicolumn{2}{|c|}{$\begin{array}{l}\text { Satisfaction with } \\
\text { functionality }\end{array}$} \\
\hline & $\beta$ & $t$ & $\beta$ & $t$ & $\beta$ & $t$ & $\beta$ & $t$ & $\beta$ & $t$ \\
\hline Importance of comfort & & & -0.15 & -2.54 & & & & & & \\
\hline Importance of territoriality & & & & & & & & & -0.31 & -5.65 \\
\hline \multicolumn{11}{|l|}{ Importance of pleasantness } \\
\hline Importance of communication & 0.13 & 2.48 & & & & & & & & \\
\hline Importance of privacy & -0.16 & -3.03 & & & & & & & & \\
\hline Effects of independent variables & $\beta$ & $t$ & $\beta$ & $t$ & $\beta$ & $t$ & $\beta$ & $t$ & $\beta$ & $t$ \\
\hline Use of cell office, conventional & 0.30 & 5.03 & & & & & & & & \\
\hline Use of open space, conventional & -0.15 & -2.82 & & & & & & & & \\
\hline Use of team office, conventional & -0.13 & -2.34 & & & & & & & 0.16 & 2.88 \\
\hline Use of open space, activity-based & & & & & 0.30 & 5.54 & -0.27 & -4.93 & & \\
\hline Use of concentr. cell, activity-based & 0.17 & 2.89 & & & & & & & & \\
\hline \multicolumn{11}{|l|}{ Age } \\
\hline \multicolumn{11}{|l|}{ Female employee (dummy) } \\
\hline \multicolumn{11}{|l|}{ Extraversion } \\
\hline Agreeableness & & & 0.12 & 2.20 & & & & & & \\
\hline Conscientiousness & & & -0.15 & -2.64 & & & & & & \\
\hline Emotional stability & 0.15 & 2.84 & & & & & & & & \\
\hline External mobility & -0.12 & -2.34 & & & & & & & & \\
\hline \multicolumn{11}{|l|}{ Time on non-concentrated work } \\
\hline Time on phone calls & & & & & & & & & & \\
\hline
\end{tabular}

er for employees that use conventional team offices $(\beta=$ $0.16 ; t=2.88$ ). In ABOs, the use of concentration cells positively affected the satisfaction with the regulation of interaction. Moreover, the use of open spaces in ABOs positively affected satisfaction with pleasantness $(\beta=$ $-0.30 ; t=-5.54)$, but negatively affected satisfaction with influence $(\beta=-0.27 ; t=-4.93)$.

The effects of the personal variables on the satisfaction scores were limited. Most of the direct effects were from personality traits. Agreeableness positively affected satisfaction with the indoor climate $(\beta=0.12 ; t=2.20)$, while conscientiousness negatively affected this satisfaction score $(\beta=-0.15 ; t=-2.64)$. Emotional stability positively affected satisfaction with the regulation of interaction $(\beta=0.15 ; t=2.84)$. It is likely that employees with lower emotional stability have more stress, and can consequently cope less with external stimuli, as explained by the environmental stress theory (Bell, Greene, Fisher, \& Baum, 2001). Last, external mobility negatively affected satisfaction with the regulation of interaction $(\beta=-0.12 ; t=-2.34)$. A cautious explanation might be that these employees spend less time at the office, and are therefore less satisfied with the (opportunities for) communication.

Because of these relationships between the perceived importance of needs and the satisfaction scores, there are also indirect effects of the independent variables, in addition to the direct effects (see Table 8). The use of open spaces in $\mathrm{ABO}$ s is indirectly positively related to satisfaction with the regulation of interaction $(\beta=0.03$; $t=2.13)$ and satisfaction with functionality $(\beta=0.06 ; t=$ $2.84)$, and negatively related to satisfaction with the indoor climate $(\beta=-0.02 ; t=-1.99)$. Also, age negatively affected satisfaction with the regulation of interaction $(\beta=-0.04 ; t=-2.25)$, indirectly through the importance of communication. On the other hand, the time spent on non-concentrated work positively affected satisfaction with the regulation of interaction $(\beta=0.03 ; t=2.12)$, indirectly through the importance of privacy. Furthermore, satisfaction with functionality was indirectly negatively affected by the time spent on phone calls $(\beta=-0.05$; $t=-2.60)$, and positively affected by external mobility $(\beta=0.06 ; t=3.10)$. However, the direct effects between these independent and dependent variables were not significant. Therefore, the mediating role of the importance of needs is not confirmed for these effects. Only for the relationship between conscientiousness and satisfaction with the indoor climate, both the direct effect $(\beta=-0.15$; $t=-2.64)$ and the indirect effect through the importance of comfort $(\beta=-0.04 ; t=-2.24)$ are significant (total effect: $\beta=-0.19 ; t=-3.36$ ). Thus, this finding indicates a mediating role of the perceived importance of comfort regarding the effect of conscientiousness on satisfaction with the indoor climate. 
Table 8. Indirect effects on satisfaction (standardized)*

\begin{tabular}{|c|c|c|c|c|c|c|c|c|c|c|}
\hline \multirow[b]{2}{*}{ Effects of independent variables } & \multicolumn{2}{|c|}{$\begin{array}{l}\text { Satisfaction with } \\
\text { regulation of } \\
\text { interaction }\end{array}$} & \multicolumn{2}{|c|}{$\begin{array}{l}\text { Satisfaction with } \\
\text { indoor climate }\end{array}$} & \multicolumn{2}{|c|}{$\begin{array}{c}\text { Satisfaction with } \\
\text { pleasantness }\end{array}$} & \multicolumn{2}{|c|}{$\begin{array}{l}\text { Satisfaction with } \\
\text { influence }\end{array}$} & \multicolumn{2}{|c|}{$\begin{array}{l}\text { Satisfaction with } \\
\text { functionality }\end{array}$} \\
\hline & $\beta$ & $t$ & $\beta$ & $t$ & $\beta$ & $t$ & $\beta$ & $t$ & $\beta$ & $t$ \\
\hline \multicolumn{11}{|l|}{ Use of cell office, conventional } \\
\hline \multicolumn{11}{|l|}{ Use of open space, conventional } \\
\hline \multicolumn{11}{|l|}{ Use of team office, conventional } \\
\hline Use of open space, activity-based & 0.03 & 2.13 & -0.02 & -1.99 & & & & & 0.06 & 2.84 \\
\hline \multicolumn{11}{|l|}{ Use of concentr. cell, activity-based } \\
\hline Age & -0.04 & -2.25 & & & & & & & & \\
\hline \multicolumn{11}{|l|}{ Female employee (dummy) } \\
\hline \multicolumn{11}{|l|}{ Extraversion } \\
\hline \multicolumn{11}{|l|}{ Agreeableness } \\
\hline Conscientiousness & & & -0.04 & -2.24 & & & & & & \\
\hline \multicolumn{11}{|l|}{ Emotional stability } \\
\hline External mobility & & & & & & & & & 0.06 & 3.10 \\
\hline Time on non-concentrated work & 0.03 & 2.12 & & & & & & & & \\
\hline Time on phone calls & & & & & & & & & -0.05 & -2.60 \\
\hline
\end{tabular}

\section{Limitations and recommendations}

The conceptual model in this study largely addresses the effects of the work environment on employee satisfaction. However, the employee can also influence the work environment, by their workspace behavior. In this study, the workspace use is not used as a dependent variable, because these variables were not normally distributed. For future research, it would therefore be of interest to test the mediating role of workspace use, and include the effects between personal characteristics, activities and workspace use, as well as the effect of needs and their importance on workspace use. Indeed, Joy and Haynes (2011) demonstrated that workspace choice differs between different generations. Similarly, Appel-Meulenbroek, Kemperman, Kleijn, and Hendriks (2015a) concluded that personal characteristics may affect workplace use. It would be interesting to include only ABOs for this purpose, because the workspace use in these offices is more varied and based on activities and personal preferences. This study not only focused on ABOs, but also on conventional offices in which workspace choice behavior is limited, so these effects were not included in this study. The effects of personal characteristics on the perceived importance of needs and hence on work environment satisfaction, however, were quite limited in this study. Possibly, these personal variables might have additional moderating variables, which are not tested in this model. Future research might also include these moderating effects. Furthermore, other variables might be added, when only focusing on the activity-based office concept. As has become clear from this study, adaptation might be relevant for satisfaction with the physical work environment. Coping might affect (the importance of) needs and satisfaction with the work environment over time. Thus, it would be interesting to include variables as resistance to change, and the time that has passed since the implementation of the ABO concept. Furthermore, the amount of preparation or training that the employees received before the implementation might be included. The latter is also endorsed by Huang, Eobertson, and Chang, (2004) and Brunia et al. (2016). Because this study also included conventional offices, these variables were not included. Additionally, more extensive job characteristics besides external mobility and activity pattern might be included in future research, particularly when investigating differences in needs.

This study only revealed one mediating effect. There were additional significant indirect effects, but the direct effects between these variables were not significant. Possibly, a larger sample might reveal more significant effects and the mediating role of more needs and preferences.

In this study, the importance of needs was asked instead of measuring the actual need. Future studies could include both measures and see to what extent they correlate. Also, it might be possible that employees put higher importance on aspects that they are not satisfied with, which is also addressed by Van der Voordt et al. (2017). So, attention should also be paid to the direction of the causality between needs and satisfaction. Moreover, other methods for data collection can be useful, in particular for the workplace use and activity patterns. Using a questionnaire to ask employees to distribute the working hours over different activities and workspaces might be less optimal, because it depends on the memory and estimation of the respondent. Therefore, observation research or diaries may lead to more accurate data.

Finally, the sample in this study only comprises Dutch organizations, and the selection of these organizations was 
not random. Therefore, the findings of this study cannot be generalized for other countries, and even for the Netherlands, the conclusions should be interpreted with care. That is, the snowball sample in this study is a limitation for the generalizability. Lastly, it might be possible that the non-response is higher for employees with specific needs or personalities, but this cannot be tested as this info is unknown for non-participants.

\section{Discussion, implications and conclusions}

This study contributes to the understanding of the effect of the physical work environment on employee satisfaction, regarding workspaces in different office concepts. Work environment satisfaction is of major importance for organizations, as it affects productivity and hence organizational performance. This study particularly provides valuable insights regarding the $\mathrm{ABO}$ concept. The results demonstrate that the $\mathrm{ABO}$ concept - and in particular the use of open spaces in these offices - has both benefits and drawbacks for work environment satisfaction.

The indoor climate is less satisfactory in $\mathrm{ABO}$ s for those that use the open spaces. The indoor climate is a common disadvantage in office environments, but particularly for open workspaces. This study showed specifically that the use of open spaces in ABOs further increases the perceived importance of comfort and thus makes the indoor climate even more important to address for workplace managers. Violation of the need for control over climate comfort in these offices might be the reason of this rise in importance. Similarly, respondents were less satisfied with influence in $\mathrm{ABOs}$ with regard to other aspects (e.g. personalization, status expression). This is also a common drawback of the $\mathrm{ABO}$ concept, due to its non-territorial use. On the other hand, the results imply that an adequate workspace use can increase environmental satisfaction in ABOs too. That is, the use of concentration cells in ABOs is positively associated with satisfaction with the regulation of interaction in this study. This is in line with Hoendervanger et al. (2015), who advocated that the misuse of workspaces in $\mathrm{ABO}$ negatively affects environmental satisfaction.

Also, $\mathrm{ABO}$ employees indicated a lower importance of privacy and territoriality, thus confirming the notion of Van der Voordt (2004) that employees eventually learn to cope with the violation of such psychological needs. Especially those employees who spend a bigger percentage of their working hours outside the office, mentioned a lower importance of having their own territory and are more satisfied with the functionality of their workspace(s). $\mathrm{ABOs}$ were originally meant for employees with higher mobility, and this study indicates that these employees are indeed more satisfied in $\mathrm{ABO}$ because they attached less importance to territoriality. Too often, $\mathrm{ABO}$ are seen as a positive solution for all employees neglecting the general job profile in the company. As this study confirmed that a higher perceived importance leads to lower satisfaction in general (just like Lee, 2006), it is important to inventory employee needs and preferences before implement- ing $\mathrm{ABOs}$. This is further confirmed by the finding that a larger portion of non-concentrated work decreases importance of privacy, so the needs of employees with these activities are likely to be violated less by the open spaces in ABOs. The study also showed that a higher importance of communication positively affected satisfaction with the regulation of interaction. Increased communication is an important expected added value of ABOs, but it is only satisfactory for those employees that value communication. Thus, the $\mathrm{ABO}$ might particularly be satisfying for employees with a higher need for communication and a lower need for privacy (i.e. relatively more non-concentrated work).

The inherent freedom and autonomy in ABOs significantly increased the importance of having more choice, good ergonomics and good aesthetics (combined into the factor called pleasantness). Workplace managers could increase the application of smart technologies and sensors to address individual ergonomics and comfort needs in ABOs. In any case, they have to make sure that they organize adequate change management processes when implementing $\mathrm{ABO}$, in order to obtain maximum benefits from it. Brunia et al. (2016) found major differences between satisfaction scores in different ABOs. Thus, the work environment should be designed adequately to meet the needs and activity patterns of the employees, in order to foster employee satisfaction.

It is interesting to notice that the used workspace in conventional offices did not affect the importance of needs. A cautious explanation might be that not the specific workspace affects needs, but the activity-based concept as a whole. The activity-based concept generally demands a change in behavior of the employees, so it is likely that this concept also interferes with their needs. In that sense the rise of $\mathrm{ABOs}$ appears to have created a reciprocal relationship between workspace and the needs, which has not yet been addressed in many previous studies.

Additionally, this study clearly shows that work environment satisfaction is not only a result of the work environment, but also of personal characteristics, such as demographics, personality, and activity patterns. However, these effects were less than expected. The study of Rothe et al. (2011) showed that personal characteristics had many effects. A possible explanation could be that Rothe et al. (2011) largely focused on preferences, while this study focuses more on the basic needs.

Overall, the model clearly showed that satisfaction with the physical work environment is a result of the P-E fit, of both environmental and personal variables. Employees differ on the importance they attach to certain needs, which not only depends on personal characteristics, but is also affected by the office environment that is used. The path model shows that the perceived importance of needs is an important determinant of work environment satisfaction. The need-based approach in this study therefore contributes to understanding satisfaction with the physical work environment in a more holistic way than in previous studies. 


\section{References}

Appel-Meulenbroek, R., Groenen, P., \& Janssen, I. (2011). An end-user's perspective on activity-based office concepts. Journal of Corporate Real Estate, 13(2), 122-135. https://doi.org/10.1108/14630011111136830

Appel-Meulenbroek, R., Kemperman, A., Kleijn, M., \& Hendriks, E. (2015a). To use or not to use: which type of property should you choose? Predicting the use of activity based offices. Journal of Property Investment \& Finance, 33(4), 320336. https://doi.org/10.1108/JPIF-09-2014-0059

Appel-Meulenbroek, R., Kemperman, A., Van Susante, P., \& Hoendervanger, J. G. (2015b, June 1-3). Differences in employee satisfaction in new versus traditional work environments. Paper presented at the Proceedings from EFMC 2015 research symposium. Glasgow, Scotland.

Bakker, I., Van der Voordt, T., Vink, P., De Boon, J., \& Bazley, C. (2015). Color preferences for different topics in connection to personal characteristics. COLOR Research and Application, 40(1), 62-71. https://doi.org/10.1002/col.21845

Batenburg, R., \& Van der Voordt, T. (2008a, June 10-11). Do facilities matter? The influence of facility satisfaction on perceived labour productivity of office employee. Paper presented at the European Facility Management Conference. Manchester, United Kingdom.

Batenburg, R., \& Van der Voordt, T. (2008b). Effecten van facilitybeleving op de gepercipieerde arbeidsproductiviteit. Delft: Center for People and Buildings.

Becker, F. (1999). Beyond alternative officing: infrastructure on demand. Journal of Corporate Real Estate, 1(2), 154-168. https://doi.org/10.1108/14630019910811006

Bell, P. A., Greene, T. C., Fisher, J. D., \& Baum, A. (2001). Environmental psychology. Orlando: Harcourt College Publishers.

Bodin-Danielsson, C., \& Bodin, L. (2008). Office type in relation to health, well-being and job satisfaction among employees. Environment and Behavior, 40(5), 636-668. https://doi.org/10.1177/0013916507307459

Bozionelos, N. (2004). The big five of personality and work involvement. Journal of Managerial Psychology, 19(1), 69-81. https://doi.org/10.1108/02683940410520664

Brennan, A., Chugh, J. S., \& Kline, T. (2002). Traditional versus open office design: a longitudinal field study. Environment and Behavior, 34(3), 279-299. https://doi.org/10.1177/0013916502034003001

Brown, G. (2009). Claiming a corner at work: measuring employee territoriality in their workspaces. Journal of Environmental Psychology, 29(1), 44-52. https://doi.org/10.1016/j.jenvp.2008.05.004

Brunia, S., De Been, I., \& Van der Voordt, T. (2016). Accommodating new ways of working: lessons from best practices and worst cases. Journal of Corporate Real Estate, 18(1), 30-47. https://doi.org/10.1108/JCRE-10-2015-0028

Brunia, S., \& Hartjes-Gosselink, A. (2009). Personalization in non-territorial offices: a study of a human need. Journal of Corporate Real Estate, 11(3), 169-182. https://doi.org/10.1108/14630010910985922

Choi, J., Aziz, A., \& Loftness, V. (2010). Investigation on the impacts of different genders and ages on satisfaction with thermal environments in office buildings. Building and Environment, 45(6), 1529-1535.

https://doi.org/10.1016/j.enbuild.2007.02.013

De Been, I., \& Beijer, M. (2014). The influence of office type on satisfaction and perceived productivity. Journal of Facilities Management, 12(2), 142-157.

https://doi.org/10.1108/JFM-02-2013-0011
Dinç, P. (2009). Gender (in) difference in private offices: a holistic approach for assessing satisfaction and personalization. Journal of Environmental Psychology, 29(1), 53-62. https://doi.org/10.1016/j.jenvp.2008.10.006

Ding, S. (2008). Users' privacy preferences in open plan offices. Facilities, 26(9-10), 401-417. https://doi.org/10.1108/02632770810885751

Duffy, F. (1997). The new office. London: Conran Octopus.

Earle, H. A. (2003). Building a workplace of choice: using the work environment to attract and retain top talent. Journal of Facilities Management, 2(3), 244-257.

https://doi.org/10.1108/14725960410808230

Ekstrand, M., Damman, S., Hansen, G. K., \& Hatling, M. (2015, June 1-3). Front and backstage in the workplace: an explorative case study on Activity Based Working and employee perceptions of control over work-related demands. Paper presented at the Proceedings from EFMC 2015 research symposium. Glasgow, Scotland.

Fleming, D. (2005). The application of a behavioural approach to building evaluation. Facilities, 23(9-10), 393-415. https://doi.org/10.1108/02632770510602342

Golob, T. (2001). Structural equation modeling for travel behavior research. Transportation Research Record, 37(1), 1-25. https://doi.org/10.1016/S0191-2615(01)00046-7

Gorgievski, M. J., Van der Voordt, T. J., Van Herpen, S. G., \& Van Akkeren, S. (2010). After the fire: new ways of working in an academic setting. Facilities, 28(3-4), 206-224. https://doi.org/10.1108/02632771011023159

Gosling, S. D., Rentfrow, P. J., \& Swann, W. B. (2003). A very brief measure of the Big-Five personality domains. Journal of Research in Personality, 37(6), 504-528. https://doi.org/10.1016/S0092-6566(03)00046-1

Haans, A., Kaiser, F. G., \& De Kort, Y. A. (2007). Privacy needs in office environments: development of two behavior-based scales. European Psychologist, 12(2), 93-102. https://doi.org/10.1027/1016-9040.12.2.93

Hartog, L., Weijs-Perrée, M., \& Appel-Meulenbroek, R. (2018). The influence of personality on user satisfaction: multi-tenant offices. Building Research \& Information, 46(4), 402-416. https://doi.org/10.1080/09613218.2017.1307015

Haynes, B. P. (2008). The impact of office comfort on productivity. Journal of Facilities Management, 6(1), 37-51.

https://doi.org/10.1108/14725960810847459

Heerwagen, J. H., Kampschroer, K., Powell, K. M., \& Loftness, V. (2004). Collaborative knowledge work environments. Building Research \& Information, 32(6), 510-528. https://doi.org/10.1080/09613210412331313025

Hills, R., \& Levy, D. (2014). Workspace design and fit-out: what knowledge workers value. Property Management, 32(5), 415432. https://doi.org/10.1080/09613210412331313025

Hoendervanger, J. G., Le Noble, V., Mobach, M. P., \& Van Yperen, N. W. (2015, June 1-3). Tool development for measuring and optimizing workplace utilization in activity-based work environments. Paper presented at the Proceedings from EFMC 2015 research symposium. Glasgow, Scotland.

Huang, Y. H., Eobertson, M. M., \& Chang, K. I. (2004). The role of environmental control on environmental satisfaction, communication, and psychological stress. Environment and Behavior, 36(5), 617-637. https://doi.org/10.1177/0013916503262543

Jahncke, H., Hygge, S., Halin, N., Green, A. M., \& Dimberg, K. (2011). Open-plan office noise: cognitive performance and restoration. Journal of Environmental Psychology, 31(4), 373382. https://doi.org/F10.1016/j.jenvp.2011.07.002 
Jensen, P. (2011). Strategy and space: a longitudinal case study of broadcasting facilities. International Journal of Strategic Property Management, 15(1), 35-47.

https://doi.org/10.3846/1648715X.2011.565868

Joy, A., \& Haynes, B. P. (2011). Office design for the multi-generational knowledge workforce. Journal of Corporate Real Estate, 13(4), 216-232. https://doi.org/10.1108/14630011111214428

Jöreskog, K., \& Sörbom, D. (2008). LISREL 8. User's reference guide. Chicago: Scientific Software International.

Kamarulzaman, N., Saleh, A. A., Hashim, S. Z., Hashim, H., \& Abdul-Ghani, A. A. (2011). An overview of the influence of physical office environments towards employees. Procedia Engineering, 20, 262-268. https://doi.org/10.1016/j.proeng.2011.11.164

Karjalainen, S. (2012). Thermal comfort and gender: a literature review. Indoor Air, 22(2), 96-109. https://doi.org/10.1111/j.1600-0668.2011.00747.x

Khamkanya, T., \& Sloan, B. (2009). Flexible working in Scottish local authority property: moving on to the highest flexibility level. International Journal of Strategic Property Management, 13(1), 37-52. https://doi.org/10.3846/1648-715X.2009.13.37-52

Kim, J., \& de Dear, R. (2013). Workspace satisfaction: the privacy-communication trade-off in open-plan offices. Journal of Environmental Psychology, 36, 18-26. https://doi.org/10.1016/j.jenvp.2013.06.007

Lee, S. Y. (2006). Expectations of employees toward the workplace and environmental satisfaction. Facilities, 24(9-10), 343353. https://doi.org/10.1108/02632770610677628

Lee, S. Y., \& Brand, J. L. (2005). Effects of control over office workspace on perceptions of the work environment and work outcomes. Journal of Environmental Psychology, 25(3), 323333. https://doi.org/10.1016/j.jenvp.2005.08.001

Maarleveld, M., Volker, L., \& Van der Voordt, T. J. (2009). Measuring employee satisfaction in new offices - the WODI toolkit. Journal of Facilities Management, 7(3), 181-197. https://doi.org/10.1108/14725960910971469

Maher, A., \& Von Hippel, C. (2005). Individual differences in employee reactions to open-plan offices. Journal of Environmental Psychology, 25, 219-229. https://doi.org/10.1016/j.jenvp.2005.05.002

Oseland, N. (2009). The impact of psychological needs on office design. Journal of Corporate Real Estate, 11(4), 244-254. https://doi.org/10.1108/14630010911006738
Roelofsen, P. (2002). The impact of office environments on employee performance: the design of the workplace as a strategy for productivity enhancement. Journal of Facilities Management, 1(3), 247-264. https://doi.org/10.1108/14725960310807944

Rothe, P., Lindholm, A. L., Hyvönen, A., \& Nenonen, S. (2011). User preferences of office occupiers: investigating the differences. Journal of Corporate Real Estate, 13(2), 81-97. https://doi.org/10.1108/14630011111136803

Sanoff, H. (1985). Attitudes towards an open plan office. Design Studies, 6(4), 196-202. https://doi.org/10.1016/0142-694X(85)90053-5

Stallworth, O. E., \& Kleiner, B. H. (1996). Recent developments in office design. Facilities, 14(1-2), 34-42. https://doi.org/10.1108/02632779610108512

Van der Voordt, D., \& Van Meel, J. (2002). Psychologische aspecten van kantoorinnovatie. Delft: Delft University of Technology \& ABN Amro.

Van der Voordt, T. J. (2004). Productivity and employee satisfaction in flexible workplaces. Journal of Corporate Real Estate, 6(2), 133-148. https://doi.org/10.1108/14630010410812306

Van der Voordt, T., Brunia, S., \& Appel-Meulenbroek, R. (2017). Satisfaction. In P. Jensen, \& T. Van der Voordt (Eds.), Facilities management and corporate real estate management as value drivers: how to manage and measure adding value (pp. 67-82). Oxfordshire: Routledge.

Veitch, J. A., Charles, K. E., Farley, K. M., \& Newsham, G. R. (2007). A model of satisfaction with open-plan office conditions: COPE field findings. Journal of Environmental Psycholo$g y, 27(3), 177-189$. https://doi.org/10.1016/j.jenvp.2007.04.002

Venezia, C., \& Allee, V. (2007). Supporting mobile worker networks: components for effective workplaces. Journal of Corporate Real Estate, 9(3), 168-182. https://doi.org/10.1108/14630010710845758

Vischer, J. C. (2008). Towards an environmental psychology of workspace: how people are affected by environments for work. Architectural Science Review, 51(2), 97-108. https://doi.org/10.3763/asre.2008.5114

Vos, P., \& Van der Voordt, T. (2002). Tomorrow's offices through today's eyes: effects of innovation in the working environment. Journal of Corporate Real Estate, 4(1), 48-65. https://doi.org/10.1108/14630010210811778 